\title{
FEATURES OF THE PEOPLE REHABILITATION POTENTIAL WITH DIFFERENT CHARACTERISTICS OF LEARNED HELPLESSNESS AND HUMAN LIFE-WORLD STABILITY
}

\author{
Olga Petriaeva ${ }^{\mathbf{1}, 2}$, Irina Loginova ${ }^{\mathbf{1}}, \boldsymbol{\&}$ Olesya Volkova ${ }^{\mathbf{1}}$ \\ ${ }^{I}$ Chair of Clinical Psychology \& Psychotherapy, Krasnoyarsk State Medical University (Russia) \\ ${ }^{2}$ Chair of Nervous Diseases with a course of Medical Rehabilitation, Krasnoyarsk State Medical \\ University (Russia)
}

\begin{abstract}
Rehabilitation potential is considered as the ability of a person to activate his biological and socio-psychological mechanisms for restoring destroyed health, employability, personal status and estate. It can be realized under the certain conditions and the consolidated assistance of rehabilitation services and society. The efforts of specialists (ergotherapists, social workers, clinical psychologists) and the closest social environment can be effective in specific conditions. The major participant of the rehabilitation activity is initially the person who needs rehabilitation. It is suggested that the problem of rehabilitation potential correlates with problem of learned helplessness of the person and problem of human life-world stability (constructive, unconstructive, stagnant). These two phenomena are similar in their definition and revealing the level of responsibility of the person for his life (Deci \& Ryan, 2000). The learned helplessness as form of human life organization is the catalyst of psychological instability and somatic illness, it determines decrease in resilience of personality to harmful influences of the external environment, contributes to the development and exacerbation of psychological damages and somatic diseases of various etiologies. The helplessness is formed and "taught" gradually, under the influence of a factor of social response to failures in life events or features of somatic health rather than level of stress factor or disease nature and their objective influence on personality (Volkova, 2016). It is very important for a person to have successful experience in overcoming difficulties. Then rehabilitation activities can rely on this positive experience and provide more confident progress of a person towards the restoration of lost functions. The human life-world stability is considered in psychology as an essential indicator of the success of the life self-fulfillment and transference of abilities inherent in him (human) into reality (Loginova, 2012). The important indicator of rehabilitation success is patients' ability to use the newly obtained functions in everyday life.
\end{abstract}

Keywords: Rehabilitation potential, learned helplessness, human life-world stability.

\section{Introduction}

In the last decade rehabilitation as the direction of medicine is constantly developing, modifying, obtaining the new features and aspects. At the same time, violation of health acts as an important condition of this concept applicability, which in this connection allows to appear various aspects of rehabilitation ("recovery treatment", "medical rehabilitation", "recovery medicine", etc.). Rehabilitation in medicine is understood as restoration of organismic functions to adequate (normal) values after any organic injury (stroke).

Nevertheless, nowadays the idea that different people are restored differently becomes obvious: with different speed, with different staging of groups of muscles inclusion, with different opportunities of result maintaining after hospital treatment. For the description of the above listed parameters of rehabilitation course the term "rehabilitation potential" was endenizened into a scientific lexicon. Rehabilitation potential includes possibilities of an organism to restoration, motivation of the patient, possibility of patient's adaptation to the world around, his socialization process, etc. The idea of rehabilitation potential is being formed according to ICF (International Classification of Functioning, restrictions of activity and health), NIHHS (National Institutes of Health Stroke Scale), Renkin scale, ICD-10 (International Statistical Classification of Diseases and Related Health Problems) and other important for ergotherapy parameters. These scales widely clasp all spheres of the patient, but can mean absolutely different defeats at the same level: for example, sedentary in a carriage and able to operate it 
perfectly patient is as well socialized, as patient walking with a unilateral support; or the patient with aphasia is as deeply struck, as the patient confined to the bed.

The analysis of scientific definition of the term "rehabilitation potential" allowed us to reveal several essential positions:

1) The concept of "the rehabilitation potential" is inexact, insufficiently clear and is affected by the influence of not clinical context (Enderby, Pandyan, Bowen, et al., 2017).

2) Rehabilitation potential is considered as the ability of a person to activate his biological and socio-psychological mechanisms for restoring destroyed health, employability, personal status and estate, but not medical stuff activity (Sivukha, Enikeeva, 1997).

3) Representation and specification of patient rehabilitation potential is necessary not only for the correct rehabilitation program development, but also for forecasting the potential efficiency of the held rehabilitation activity (Haselbach, Renggli, Carda, et al., 2014), for estimation of the possible restoration level of a broken function and, therefore, the rehabilitation forecast.

4) The described in the contemporary studies clinical cases indicate the possibility of gradual change concerning the rehabilitation potential level: initially all patients by default have high rehabilitation potential and take a usual rehabilitation course, but during the subsequent hospitalization at the same medical institution doctors can estimate the remote results and change the level of rehabilitation potential. However, patients with various psychological characteristics can have problems with restoration of functions already at the first stage of rehabilitation that demands inclusion of the clinical psychologist in multidisciplinary team on a constant basis (Petryaeva, Shnayder, Artyukhov, Sapronova, Loginova, 2017).

We suggested that the problem of rehabilitation potential correlates with problem of learned helplessness of the person and problem of human life-world stability (constructive, unconstructive, stagnant). These two phenomena are similar in their definition and revealing the level of responsibility of the person for his life (Deci \& Ryan, 2000).

The learned helplessness as form of human life organization is the catalyst of psychological instability and somatic illness, it determines decrease in resilience of personality to harmful influences of the external environment, contributes to the development and exacerbation of psychological damages and somatic diseases of various etiologies. The helplessness is formed and "taught" gradually, under the influence of a factor of social response to failures in life events or features of somatic health rather than level of stress factor or disease nature and their objective influence on personality (Volkova, 2017).

It is very important for a person to have successful experience in overcoming difficulties. Then rehabilitation activities can rely on this positive experience and provide more confident progress of a person towards the restoration of lost functions.

The human life-world stability is considered in psychology as an essential indicator of the success of the life self-fulfillment and transference of abilities inherent in him (human) into reality (Loginova, 2012).

\section{Design}

The study was of comparative type and was organized in the two samples to reveal the degree of difference manifestation. All respondents subscribed voluntary informed consent to participate in the study in accordance with the norms of the Local Ethics Committee of Krasnoyarsk State Medical University. The study was conducted from 2017 until 2018.

Criteria of inclusion in the research:

- patients with a trauma of cervical section of the spine as one of the most severe injuries on consequences for the human;

- agreement to participate in the study subscribed in the informed consent;

- duration of a disease is no more than two years;

- status of a graduate (to provide high cognitive inclusiveness);

- age up to 50 years (to avoid cases of dementia processes influence on the research data);

- existence of close social environment for providing psychological support in rehabilitation process;

- the number of hospitalizations is more than one previous (that indicates adaptability to rehabilitation process);

- no more than one serious associated disease in anamnesis.

40 people were involved in the study.

The general number of patients was divided into two groups according to the level of rehabilitation potential.

- The first group - patients with low level of rehabilitation potential.

- The second group - patients with high level of rehabilitation potential. 


\section{Objectives}

The aim of the research is to study the features of the patients' rehabilitation potential with different characteristics of learned helplessness and human life-world stability:

The main objectives of the research are: potential?

1) To explore how the state of the learned helplessness influences the features of rehabilitation

2) To reveal how the specifics of human life-world stability influence the features of rehabilitation potential?

\section{Methods}

At the preparatory investigation stage, the assessment of rehabilitation potential was carried out by means of the following methods:

- neurologic (Renkin Scale, Bartel Index, OSS (Orgogozo Stroke Scale), ECOG (Karnovsky Index), RMI (Rivermead Mobility Index)),

- psychological (SF36, Riff scale, EPQ, E.B. Fantalova's questionnaire, BAI (Beck Anxiety Inventory), Cattel Sixteen Personality Factor Questionnaire, Dembo-Rubenstein test),

- neuropsychological techniques (MMSE, MOCA)

with deciphering of their result.

These scales are validated and have clear evidential base. The assessment of rehabilitation potential (high, average or low) was provided on the basis of the obtained data.

The open-type questionnaire "Learned Helplessness Genesis Value Judgment" (Volkova, 2016) was applied to study the unique ways of learned helplessness development and identification of its place in life of a specific person.

The method "Investigation of the Human Life-World Stability" (Loginova, 2012) was used as the research tool, which allows to study the features of the human life-world stability in the process of real-life activity. This method is aimed at studying the features of the human life organization and allows revealing the manifestations of the life stability (constructive, unconstructive, and stagnant).

Mathematical processing of the obtained results was carried out with use of the SPSS Statistics 21 software packaging.

\section{Discussion}

All data (responses and quotations) obtained in the two groups of respondents by means of the open-type questionnaire "Learned Helplessness Genesis Value Judgment" (Volkova, 2016) were systematized in accordance with the instruction and are presented in Table 1.

Table 1. Results of the questionnaire "Learned Helplessness Genesis Value Judgment".

\begin{tabular}{|c|c|c|c|c|}
\hline \multirow{2}{*}{$\begin{array}{l}\text { Learned } \\
\text { helplessness } \\
\text { criteria }\end{array}$} & \multicolumn{2}{|c|}{$1^{\text {st }}$ group } & \multicolumn{2}{|c|}{$2^{\text {nd }}$ group } \\
\hline & Before disease & During disease & Before disease & During disease \\
\hline $\begin{array}{l}\text { Estimation of } \\
\text { the health state } \\
\text { (somatic status) }\end{array}$ & $\begin{array}{l}\text { I was diagnosed } \\
\text { with prematurity at } \\
\text { my birth } \\
\text { Frequent diseases of } \\
\text { various genesis } \\
\text { Asthenia } \\
\end{array}$ & $\begin{array}{l}\text { I feel deeply sick } \\
\text { I do not feel } \\
\text { healthy } \\
\text { I'm not alive, there } \\
\text { is no life in me }\end{array}$ & $\begin{array}{l}\text { Sometimes I suffered from } \\
\text { viral diseases } \\
\text { Something rarely } \\
\text { happened } \\
\text { I always considered } \\
\text { myself as healthy }\end{array}$ & $\begin{array}{l}\text { I'm overcoming the } \\
\text { disease } \\
\text { I do not define } \\
\text { myself as a patient } \\
\text { I'm restoring }\end{array}$ \\
\hline $\begin{array}{l}\text { Estimation of } \\
\text { the emotional } \\
\text { state }\end{array}$ & $\begin{array}{l}\text { I was morally } \\
\text { humiliated in my } \\
\text { family } \\
\text { I suffered from } \\
\text { experiencing } \\
\text { difficult life periods } \\
\text { Life has broken me, } \\
\text { I'm broken }\end{array}$ & $\begin{array}{l}\text { The trauma cracked } \\
\text { me even more } \\
\text { I am emotionally } \\
\text { devastated } \\
\text { I have no energy } \\
\text { for emotion }\end{array}$ & $\begin{array}{l}\text { Positive experiences of joy } \\
\text { from openings, } \\
\text { communication, } \\
\text { achievements }\end{array}$ & $\begin{array}{l}\text { Experiences of } \\
\text { impossibility to be } \\
\text { active, other } \\
\text { emotional reactions } \\
\text { remained the same }\end{array}$ \\
\hline $\begin{array}{l}\text { Estimation of } \\
\text { the motivation } \\
\text { level }\end{array}$ & $\begin{array}{l}\text { I always wanted to } \\
\text { be active, but it was } \\
\text { impossible }\end{array}$ & $\begin{array}{l}\text { There is no desire } \\
\text { to be active } \\
\text { I accepted this } \\
\text { situation (disease), } \\
\text { there is no } \\
\text { motivation on } \\
\text { changing it }\end{array}$ & $\begin{array}{l}\text { I was active, I clearly } \\
\text { understood what I want } \\
\text { I was strongly motivated } \\
\text { on achievements } \\
\text { I always competed with } \\
\text { others and myself }\end{array}$ & $\begin{array}{l}\text { I am ready to fight } \\
\text { for health } \\
\text { I have experience of } \\
\text { achievements, I use } \\
\text { it for achieving } \\
\text { results }\end{array}$ \\
\hline
\end{tabular}




\begin{tabular}{|c|c|c|c|c|}
\hline $\begin{array}{l}\text { Estimation of } \\
\text { the will-power } \\
\text { level }\end{array}$ & $\begin{array}{l}\text { Everything came } \\
\text { easily for me, I } \\
\text { never trained my } \\
\text { will-power } \\
\text { The will was weak - } \\
\text { I could achieve } \\
\text { nothing through } \\
\text { efforts }\end{array}$ & $\begin{array}{l}\text { If someone who } \\
\text { would direct me is } \\
\text { absent, I do nothing }\end{array}$ & $\begin{array}{l}\text { I was always a strong- } \\
\text { willed person } \\
\text { I was always on friendly } \\
\text { terms with my will-power: } \\
\text { I can do everything } \\
\text { overcoming my thought "I } \\
\text { do not want" to complete } \\
\text { anything I've started doing }\end{array}$ & $\begin{array}{l}\text { Now I became } \\
\text { weaker, wanted to } \\
\text { give up smoking, but } \\
\text { didn't succeed in it } \\
\text { I try to overcome the } \\
\text { situation: it's } \\
\text { impossible to reach } \\
\text { anything without } \\
\text { efforts }\end{array}$ \\
\hline $\begin{array}{l}\text { Locus of control } \\
\text { estimation }\end{array}$ & $\begin{array}{l}\text { While parents were } \\
\text { alive, they } \\
\text { controlled me. } \\
\text { When they died - it } \\
\text { was necessary to } \\
\text { become independent } \\
\text { Support of people } \\
\text { around me was } \\
\text { always necessary }\end{array}$ & $\begin{array}{l}\text { Now external } \\
\text { control is very } \\
\text { important (the } \\
\text { doctor, the nurse) } \\
\text { Without someone } \\
\text { who "adjusts" I } \\
\text { cannot do anything }\end{array}$ & $\begin{array}{l}\text { Generally, is was } 50 / 50 \\
\text { It differs from situation to } \\
\text { situation, but I tried to } \\
\text { control everything myself } \\
\text { I was accustomed to rely } \\
\text { on opinion of only the } \\
\text { closest - that's the way I } \\
\text { lived }\end{array}$ & $\begin{array}{l}\text { Now in those aspects } \\
\text { where I am not an } \\
\text { expert (concerning } \\
\text { treatment), I do not } \\
\text { interfere - I trust } \\
\text { experts } \\
\text { Situationally, about } \\
50-70 \% \text { is of my } \\
\text { control }\end{array}$ \\
\hline $\begin{array}{l}\text { Estimation of } \\
\text { cognitive sphere }\end{array}$ & $\begin{array}{l}\text { Though I was ill in } \\
\text { the childhood, I was } \\
\text { smart } \\
\text { I studied well at } \\
\text { school } \\
\text { I was a middling }\end{array}$ & $\begin{array}{l}\text { I try to maintain } \\
\text { my wits working } \\
\text { I puzzle crosswords }\end{array}$ & $\begin{array}{l}\text { My development was } \\
\text { normal } \\
\text { I never had problems with } \\
\text { study } \\
\text { I had excellent memory }\end{array}$ & $\begin{array}{l}\text { I do not notice any } \\
\text { deterioration so far } \\
\text { Everything is } \\
\text { interesting, I read a } \\
\text { lot }\end{array}$ \\
\hline $\begin{array}{l}\text { General } \\
\text { atmosphere in } \\
\text { child-parental } \\
\text { relations }\end{array}$ & $\begin{array}{l}\text { In my childhood I } \\
\text { was beaten by } \\
\text { parents } \\
\text { I was afraid of } \\
\text { parents } \\
\text { I did everything my } \\
\text { parents wanted only } \\
\text { because of their } \\
\text { rigid style of } \\
\text { education }\end{array}$ & $\begin{array}{l}\text { I do not want to be } \\
\text { a burden to my } \\
\text { children } \\
\text { I have difficult } \\
\text { relations with my } \\
\text { relatives }\end{array}$ & $\begin{array}{l}\text { We had a great family, I } \\
\text { have built my own family } \\
\text { by this example } \\
\text { Parents always understood } \\
\text { me } \\
\text { I was never shouted at, } \\
\text { parents explained me } \\
\text { everything }\end{array}$ & $\begin{array}{l}\text { My relations with } \\
\text { family remained } \\
\text { wonderful } \\
\text { I feel support } \\
\text { All relatives are } \\
\text { ready to help me }\end{array}$ \\
\hline $\begin{array}{l}\text { General } \\
\text { characteristic of } \\
\text { relations with } \\
\text { social } \\
\text { environment }\end{array}$ & $\begin{array}{l}\text { I had no friends } \\
\text { I was a soul of any } \\
\text { company } \\
\text { It was pleasant to } \\
\text { communicate }\end{array}$ & $\begin{array}{l}\text { I limited } \\
\text { communication } \\
\text { because of the } \\
\text { defect } \\
\text { I am ashamed of } \\
\text { friends as I am a } \\
\text { disabled person } \\
\text { I do not } \\
\text { communicate with } \\
\text { anybody, except } \\
\text { relatives }\end{array}$ & $\begin{array}{l}\text { Communication brought } \\
\text { me pleasure } \\
\text { I always was in the center } \\
\text { of events, possessed all the } \\
\text { information } \\
\text { I trusted to my social } \\
\text { environment }\end{array}$ & $\begin{array}{l}\text { My friends and } \\
\text { acquaintances often } \\
\text { visit me } \\
\text { I communicate } \\
\text { actively in social } \\
\text { networks } \\
\text { People often ask me } \\
\text { for advice }\end{array}$ \\
\hline
\end{tabular}

All results of the two groups of respondents obtained by means of the method "Investigation of the Human Life-World Stability" were systematized in accordance with the instruction and are presented in Table 2.

Table 2. Results of method "Investigation of the Human Life-World Stability"

\begin{tabular}{|l|l|l|}
\hline \multicolumn{1}{|c|}{ Options } & \multicolumn{1}{|c|}{$1^{\text {st } \text { group }}$} & \multicolumn{1}{c|}{$2^{\text {nd }}$ group } \\
\hline Temporarity of events tendency & $\begin{array}{l}\text { The present 30\% } \\
\text { The past 40\% } \\
\text { The past - the present 30\% }\end{array}$ & $\begin{array}{l}\text { The present - the future 70\% } \\
\text { The past - the present - the future 30\% }\end{array}$ \\
\hline The ratio of verbs & $\begin{array}{l}\text { The present } 40 \% \\
\text { The past 40\% } \\
\text { The past - the present 20\% }\end{array}$ & $\begin{array}{l}\text { The present - the future 70\% } \\
\text { The past - the present - the future 30\% }\end{array}$ \\
\hline $\begin{array}{l}\text { Criterion for the described } \\
\text { events content selecting }\end{array}$ & $\begin{array}{l}\text { Chronotopic 10\% } \\
\text { Topological 30\% } \\
\text { Biographical 60\% }\end{array}$ & $\begin{array}{l}\text { Chronotopic 40\% } \\
\text { Topological 50\% } \\
\text { Biographical 10\% }\end{array}$ \\
\hline $\begin{array}{l}\text { General emotional background } \\
\text { of events }\end{array}$ & $\begin{array}{l}\text { Positive 10\% } \\
\text { Neutral 40\% } \\
\text { Negative 50\% }\end{array}$ & $\begin{array}{l}\text { Poutive } 70 \% \\
\text { Negative } 10 \%\end{array}$ \\
\hline
\end{tabular}




\begin{tabular}{|c|c|c|}
\hline $\begin{array}{l}\text { The meaning of the described } \\
\text { life events }\end{array}$ & $\begin{array}{l}\text { The overall direction of the } \\
\text { development line is conserved } 20 \% \\
\text { General orientation is not withheld } \\
20 \% \\
\text { Center of the development line } 20 \% \\
\text { Completion of the development line } \\
40 \%\end{array}$ & $\begin{array}{l}\text { The overall direction of the } \\
\text { development line is conserved } 60 \% \\
\text { General orientation is not withheld } \\
30 \% \\
\text { The beginning of the development line } \\
10 \%\end{array}$ \\
\hline Attitude to events & $\begin{array}{l}\text { Valuable } 10 \% \\
\text { Responsible } 10 \% \\
\text { Rational } 80 \%\end{array}$ & $\begin{array}{l}\text { Valuable } 70 \% \\
\text { Responsible } 20 \% \\
\text { Rational } 10 \% \\
\end{array}$ \\
\hline Continuity of personal story & $\begin{array}{l}\text { Retained } 10 \% \\
\text { Situational 30\% } \\
\text { Missing } 60 \% \\
\end{array}$ & $\begin{array}{l}\text { Retained } 70 \% \\
\text { Situational } 20 \% \\
\text { Missing } 10 \% \\
\end{array}$ \\
\hline Creative reflexive position & $\begin{array}{l}\text { Holistic reflexive position } 10 \% \\
\text { Situational reflexive attitude } 30 \% \\
\text { Absence of a reflexive relation } 60 \%\end{array}$ & $\begin{array}{l}\text { Holistic reflexive position } 70 \% \\
\text { Situational reflexive attitude } 20 \% \\
\text { Absence of a reflexive relation } 10 \%\end{array}$ \\
\hline
\end{tabular}

\section{Conclusions}

It was revealed that people with low rehabilitation potential had problems during the childhood or youth period which promoted formation of the learned helplessness syndrome. The difficulties in the course of personality development significantly reduce possibilities of present recovery period. It is hard for such patients to cope with difficulties independently, as an active person, from the subjective position. They narrow life space because of defect, experience mainly negative feelings and emotions. Besides, their life has fragmentary character: it is broken into two parts "before the disease" and "during the disease". They feel fear thinking about their future. They are not focused on the reflexive attitude to life and themselves. Their critical thinking is reduced.

As for patients with high rehabilitation potential they have resource for restoration during disease: they are optimistic, capable to control their own life, keep social contacts, try to be useful to others. Their life is represented as more complete, complex, filled with sense. They are capable to learn experience from current situation and to give support to people around.

The important indicator of rehabilitation success is patients' ability to use the newly obtained functions in everyday life. However, only $60 \%$ of patients with low rehabilitation potential demonstrate the ability to transfer the mastered skills to everyday life. We suppose that there are two major obstacles to it: the learned helplessness manifestations and not constructive or stagnant human life-world stability.

\section{References}

Deci, E.L., Ryan, R.M. (2000). The "What" and "Why" of goal pursuits: human needs and the self-determination of behavior. Psychological Inquiry, Vol. 11, 4, 227-268.

Enderby, P., Pandyan, A., Bowen, A., Hearnden, D., Ashburn, A., Conroy, P., Logan, P., Thompson, C., Winter, J. (2017). Accessing Rehabilitation after Stroke - A Guessing Game? Disabilitation Rehabilitation, 39 (7), 709-713. doi: 10.3109/09638288.2016.1160448.

Haselbach, D., Renggli, A., Carda, S., Croquelois, A. (2014). Determinants of neurological functional recovery potential after stroke in young adults. Cerebrovasc Dis Extra, 4, 77-83. doi: $10.1159 / 000360218$.

Loginova, I.O. (2012). Research of stability of the vital world of the person: technique and psychometric characteristics. Psychological Science and Education, 3, 18-28.

Petryaeva, O.V., Shnayder, N.A., Artyukhov, I.P., Sapronova, M.R., Loginova, I.O. (2017). The role of orthotic service in modern rehabilitation of patients with Charcot-Marie-Tooth disease. Journal of Biosciences and Medicines, 6, 23-34.

Sivukha, T.A., Enikeeva, A.A. (1997). Methodical approaches to determining the rehabilitation of the brain vascular pathology. Medico-social examination and rehabilitation of disabled people, 21, 63-69.

Volkova, O.V. (2016). Prospects of a complex research model application in designing the program aimed to diagnostics, correction and prevention of the learned helplessness in ontogenesis. Siberian psychological journal, 61, 47-63. 